\title{
ТРАНСНАЦИОНАЛЬНЫЕ БАНКИ КАК ВАЖНЕЙШИЕ СУБЪЕКТЫ МИРОВОЙ ВАЛЮТНОЙ СИСТЕМЫ
}

\begin{abstract}
Аннотация: В статье исследуется одна из ключевых тенденций развития мировой валютной системы в условиях финансовой глобализации - усиление транс-национализации мировых и европейских банков, в том числе, стран СНГ и России, степень экспорта банковских услуг в другие страны. Анализируется тенденция увеличения активов системно значимых финансовых учреждений, а также процентного соотношению величины активов крупнейших банков и совокупных банковских активов стран Евросоюза к ВВП страны базирования, отражающего степень влияния банковской системы и отдельных крупнейших банков на реальную экономику.

В статье показано, что проблемы отдельных крупнейших банков могут стать проблемами целых стран и мировой валютно-финансовой системы в целом. Рассмотрены меры, принимаемые МВФ, Евросоюзом и Россией для повышения экономической безопасности, обеспечения долгосрочной устойчивости мировой валютно-финансовой системы, а также создания эффективной регуляторной и надзорной политики за деятельностью крупнейших ТНБ мира и Европы.
\end{abstract}

Ключевые слова: Экономика, глобализачия, система, транснационализация, экспорт, банк, регуляторы, политика, ТНБ, безопасность

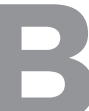

ажным элементом мировой валютной системы является валютный рынок, главная функция которого состоит в обеспечении потребности его участников в иностранной валюте для осуществления международных расчетов, управления ликвидностью, страхования валютных рисков, а также извлечению прибыли из операций с иностранной валютой. С институциональной точки зрения валютный рынок - это совокупность различных экономических агентов (субъектов), осуществляющих валютные операции.

Новые качественные и количественные характеристики мирового валютно-финансового рынка в современных условиях экономической глобализации дополняются изменениями его институциональной структуры, представленной значительной совокупностью кредитно-финансовых институтов, участвующих в валютных и финансовых операциях, осуществляющих перераспределение капиталов между странами, участвующими в международном разделении труда.

По степени участия в процессе воспроизводства капитала всех участников мирового валютного рынка можно разделить на три основные группы:

- $\quad$ транснациональные банки (ТНБ), валютные и фондовые биржи, валютные брокеры;
- $\quad$ международные портфельные инвесторы (пенсионные и страховые фонды, хедж-фонды, институты коллективного инвестирования и т.п.); - международные официальные институты (центральные банки, правительственные органы, международные и региональные организации) $[10$, С.20].

Традиционными участниками мирового валютного рынка продолжают оставаться как коммерческие, так и инвестиционные транснациональные банки, совершающие валютные операции между собой и с торгово-промышленными корпорациями.

ТНБ можно рассматривать как финансовую разновидность транснациональных корпораций (ТНК), которые выступают главными материальными носителями усиливающейся транснационализации экономической деятельности [8]. Усиление роли ТНБ, как проявление процесса транснационализации мировой экономики, имеет непосредственное отношение к трансформационным особенностям, характерным для мировой валютной системы на современном этапе. ТНБ - важнейший сегмент этой системы и одновременно фактор, воздействующий на ее развитие. Если ТНК выступают в качестве главного звена развития процесса глобализации в создании мирового валового продукта, ТНБ - это 


\section{Национальная безопасность 2(25) • 2013}

главная двигательная система процесса глобализации в финансовом сегменте мировой экономики. ТНБ являются основными экономическими агентами мирового валютного рынка.

Углубление процесса глобализации сопровождается возрастанием роли ТНБ, представляющих крупные многопрофильные финансово-банковские холдинги, располагающие широкой сетью зарубежных дочерних подразделений и филиалов.
По состоянию на 01.10.2012 г. активы, контролируемые 10 крупнейшими в мире ТНБ, составили более 25,62 трлн. долл., увеличившись на 11,54\% по сравнению 01.01.2009 г. (22,97 трлн. долл.) (табл. 1). Аккумулируя и перераспределяя между странами огромные массы денежного капитала, ТНБ влияют на увеличение его объема и направления межстранового движения, динамику курсов валют и других финансовых активов [2].

Таблицуа 1 Динамика увеличения активов крупнейших банков мира за период 2009-2012 г2., млрд. долл. США

\begin{tabular}{|c|c|c|c|c|c|c|c|}
\hline Рейтинг & Банк & Страна & 01.10.12 & 01.01.12 & 01.01.11 & 01.01 .10 & 01.01.09 \\
\hline 1 & Deutsche Bank & Германия & 2809,89 & 2802,71 & 2551,30 & 2153,00 & 2895,50 \\
\hline 2 & $\begin{array}{l}\text { Mistsubishi UFJ Financial } \\
\text { Group }\end{array}$ & Япония & 2803,42 & 2741,52 & 2158,50 & 2196,00 & 1922,18 \\
\hline 3 & $\begin{array}{l}\text { Industrial \& Commercial } \\
\text { Bank of China }\end{array}$ & Китай & 2763,59 & 2455,59 & 2040,70 & 1726,00 & 1425,72 \\
\hline 4 & HSBC Holding & Великобритания & 2721,06 & 2555,58 & 2454,70 & 2356,00 & 2527,47 \\
\hline 5 & Barclays PLC & Великобритания & 2584,30 & 2430,74 & 2325,70 & 2227,00 & 3004,33 \\
\hline 6 & BNP Paribas & Франция & 2562,99 & 2545,34 & 2674,60 & 2952,00 & 2729,23 \\
\hline 7 & Japan Post Bank & Япония & 2513,21 & 2542,77 & $* * *$ & $* * *$ & $* * *$ \\
\hline 8 & JPMorgan Chase \& Co. & США & 2321,28 & 2265,79 & 2117,60 & 2032,00 & 2175,05 \\
\hline 9 & Credit Agricole SA & Франция & $2317.12 *$ & 2434,24 & 2133,00 & 2234,00 & 2173,89 \\
\hline 10 & $\begin{array}{l}\text { Royal Bank of Scotland } \\
\text { Group }\end{array}$ & Великобритания & 2225,14 & 2342,66 & 2267,90 & 2739,00 & 3514,58 \\
\hline 11 & Bank of America & США & 2168,02 & 2129,05 & 2264,90 & 2223,00 & 1817,94 \\
\hline 12 & Mizuho Financial Group & Япония & 2123,32 & 2098,18 & 1708,30 & 1637,00 & 1537,92 \\
\hline 13 & China Construction Bank & Китай & 2115,35 & 1948,66 & 1634,50 & 1409,00 & 1104,01 \\
\hline 14 & Agricultural Bank of China & Китай & 2078,03 & 1852,79 & 1567,50 & 1301,00 & $* *$ \\
\hline 15 & Bank of China & Китай & 2027,41 & 1876,98 & 1581,50 & 1281,00 & 1015,79 \\
\hline 16 & Citi group Inc & США & 1931,35 & 1874,91 & 1913,90 & 1857,00 & 1938,47 \\
\hline 17 & $\begin{array}{l}\text { Sumitomo Mitsui Financial } \\
\text { Group }\end{array}$ & Япония & 1788,23 & 1805,09 & 1326,80 & 1281,00 & 1115,06 \\
\hline 18 & Banco Santander & Испания & 1672,11 & 1620,92 & 1629,70 & 1593,00 & 1464,74 \\
\hline
\end{tabular}


DOI: $10.7256 / 2073-8560.2013 .02 .3$

Система и взаимодействия

\begin{tabular}{|l|l|l|r|r|r|r|r|}
\hline 19 & Societe Generale & Франция & 1647,51 & 1530,09 & 1515,30 & 1469,00 & 1485,89 \\
\hline 20 & ING Group & Нидерланды & 1604,57 & 1656,74 & 1647,00 & 1668,00 & 1858,31 \\
\hline
\end{tabular}

* - Данные представлены по состоянию на 30.06.2012 г.

** - с 15.01.2009 банк был реструктурирован в коммерческий банк акционерного типа, до указанной даты находился под контролем государства.

*** - осуществлялась реорганизация банка (приватизация).

Составлено автором по: [14].

Таблица 2 Динамика увеличения активов крупнейших банков Европь за период 2009-2012 ге., млрд. долл. США

\begin{tabular}{|c|l|l|r|r|r|r|r|}
\hline Рейтинг & \multicolumn{1}{|c|}{ Банк } & \multicolumn{1}{|c|}{ Страна } & $\mathbf{0 1 . 0 4 . 1 2}$ & $\mathbf{0 1 . 0 1 . 1 2}$ & $\mathbf{0 1 . 0 1 . 1 1}$ & $\mathbf{0 1 . 0 1 . 1 0}$ & $\mathbf{0 1 . 0 1 . 0 9}$ \\
\hline 1 & Deutsche Bank & Германия & 2805,50 & 2802,71 & 2551,30 & 2153,00 & 2895,50 \\
\hline 2 & HSBC Holdings & Великобритания & 2637,22 & 2555,58 & 2454,70 & 2356,00 & 2527,47 \\
\hline 3 & BNP Paribas & Франция & $2545,34 *$ & 2545,34 & 2674,60 & 2952,00 & 2729,23 \\
\hline 4 & Credit Agricole Group & Франция & 2514,81 & 2434,24 & 2133,00 & 2234,00 & 2173,89 \\
\hline 5 & Barclay PLC & Великобритания & $2430,74 *$ & 2430,74 & 2325,70 & 2227,00 & 3004,33 \\
\hline 6 & Royal Bank of Scotland & Великобритания & 2246,52 & 2342,66 & 2267,90 & 2739,00 & 3514,58 \\
\hline 7 & Group & Испания & 1712,05 & 1620,92 & 1613,40 & 1593,00 & 1464,74 \\
\hline 8 & ING Group & Нидерланды & 1656,88 & 1656,74 & 1647,00 & 1668,00 & 1858,31 \\
\hline 9 & Societe Generale & Франция & 1592,72 & 1530,09 & 1515,30 & 1469,00 & 1485,89 \\
\hline 10 & Lloyds Banking Group & Великобритания & 1548,00 & 1508,86 & 1549,50 & 1659,00 & 638,09 \\
\hline 11 & Groupe BPCE & Франция & 1540,24 & 1473,88 & 1403,40 & 1482,00 & 367,30 \\
\hline 12 & UBS & Швейцария & 1514,15 & 1510,95 & 1400,10 & 1297,00 & 1740,27 \\
\hline 13 & Uni Credit S.p.A. & Италия & 1244,75 & 1200,31 & 1244,20 & 1333,00 & 1459,10 \\
\hline 14 & Credit Suisse Group & Швейцария & 1108,61 & 1117,02 & 1096,90 & 997,71 & 1010,32 \\
\hline 15 & Rabobank Group & Нидерланды & 947,62 & 947,62 & 873,45 & 871,88 & 854,17 \\
\hline 16 & Nordea Bank & Швеция & 925,83 & 927,59 & 769,73 & 728,18 & 623,38 \\
\hline 17 & Commerzbank & Германия & 921,83 & 857,13 & 1009,70 & 1211,00 & 872,45 \\
\hline 18 & Intesa Sanpaolo & Италия & 870,64 & 827,89 & 881,78 & 896,48 & 836,48 \\
\hline 19 & BBVA & Испания & 801,09 & 774,10 & 732,49 & 767,67 & 713,55 \\
\hline 20 & Standard Chartered & Великобритания & 799,19 & 599,07 & 516,54 & 435,56 & 435,07 \\
\hline
\end{tabular}

* - Данные представлены по состоянию на 31.12.2011 г.

Составлено автором по [14]. 


\section{Национальная безопасность 2(25) • 2013}

Среди наиболее крупных банков мира европейские банки занимают лидирующие позиции. Так среди 10 крупнейших мировых банков шесть банков - европейские.

Немецкий банк Deutsche Bank, активы которого по состоянию на 01.10.2012 составили 2809,89 млрд. долл., за последние 5 лет из крупнейшего банка Германии превратился в глобальный инвестиционный банк, имеющий свои подразделения в 70 странах мира, в том числе, Европе, Америке, АзиатскоТихоокеанском регионе, а так же в странах с трансформирующейся экономикой, обслуживая клиентов в 3000 отделениях (1946 отделений - в Германии). В апреле 2010 банком был приобретен в Голландии Bank ABNAMRON.V. В ноябре 2010 Deutsche Bank приобрел долю в 51,98\% в Deutsche Postbank AG [14].

Вторым ТНБ мира по величине активов является японский банк Mitsubishi UFJ Financial Group (MUFG) [14], совокупные активы которого по состоянию на 01.10.2012 г. составили 2803,42 млрд. долл., что на $0,23 \%$ меньше активов немецкого Deutsche Bank, занимающего первую строчку крупнейших банков мира. MUFG состоит из 5 основных компаний, включая Bank of Tokyo-Mitsubishi UFJ (BTMU), Mitsubishi UFJ Trust and Banking Corporation, Mitsubishi UFJ Securities Holding, Mitsubishi UFJ NICOS и Mitsubishi UFJ Lease\&Finance. MUFG был образован путем слияния Mitsubishi Tokyo Financial Group (MTFG) и UFJ Holding в 2005 году. MUFG - одна из главных компаний Mitsubishi Group. У Группы есть самая большая международная сеть подразделений более чем в 40 странах мира. Так в Северной Америке MUFG работает через BTMU, Union Bank и Mitsubishi UFJ Securities.

Третью строчку среди крупнейших банков мира занимает Индустриальный и Коммерческий банк Китая ICBC (Industial and Commercial Bank of China) [20], являющийся самым большим по активам банком Китая и одним из «Большой четверки» принадлежащих государству коммерческих банков (70\%). Его совокупные активы на 1,65 \% меньше активов Deutsche Bank. ICBC является и крупнейшим банком мира по рыночной капитализации (241 млрд. долл. по состоянию на январь 2012 г.). Обслуживает более 219 миллионов клиентов через 16200 отделений по всей стране, 162 зарубежных филиалов, имеющих корреспондентские счета более чем с 1504 банками мира.

Банк Великобритании HSBC Holding plc [19], занимающий четвертую строчку крупнейших мировых банков (на $3,16 \%$ совокупные активы меньше, чем у самого крупного банка мира), является одной из крупнейших финансовых компаний мира, которая обслуживает более чем 95 миллионов клиентов через международную сеть, состоящую из 7500 офисов в 88 странах мира: Европы; Азии, включая Ближний Восток; Африки; Северной и Южной Америке.

Вторым крупнейшим банком Великобритании, занимающим 5 строчку крупнейших банков мира, является Barclays PLC [15] с совокупными банковскими активами 2584,30 млрд. долл. (на 8.03\% меньше, чем у самого крупного банка мира по состоянию на 01.10.2012 г.). Barclays PLC представляет собой мировую транснациональную корпорацию по оказанию финансовых услуг. Через свои подразделения осуществляет финансовые операции более чем в 50 странах Европы, Азии, Африки, Северной и Южной Америке и обслуживает более 50 миллионов клиентов во всем мире. В 2008 году Barclays приобрел инвестиционный банк Северной Америки Lehman Brothers Nord American. В 2009 г. закончил приобретение частного банка PT Akita, имеющего 10 подразделений в трех городах Индонезии. В 2010 г. Barclays приобрел итальянский Citibank International Bank. В марте 2011 г. банком были приобретены активы Egg's UK credit card. В 2010 году Barclays реорганизовал свою деятельность, сформировав три бизнес - группировки: Global Retail Banking (GRB), CIB \& Barclay Wealth и Absa, являющуюся одним из крупнейших финансовых учреждений в Южной Африке.

Среди крупнейших банков Европы Deutsche Bank также занимает первую позицию и (табл. 2). При этом совокупные активы 10 крупнейших банков Европы по состоянию на 01.04.2012 г. составляли 21,69 трлн. долл., что на $3 \%$ больше, чем на 01.01.2009, что свидетельствует о восстановлении банковской системы Европы после глобального валютно-финансового кризиса.

Величина совокупных активов 10 крупнейших банков Европы, размещенных в Великобритании, Германии, Франции, Испании и Нидерландах, составляет $84,66 \%$ от совокупных активов 10 крупнейших банков мира, что свидетельствует о том, что европейские банки занимают важнейшее место в мировой валютной системе. Так половина самых больших по активам банков мира, вошедших в первую тридцатку самых крупных банков, в 2011 г. были банки Евросоюза.

Мировые совокупные банковские активы в 2011 были в 1,58 раз больше чем совокупный мировой ВВП (таб. 3). 
DOI: $10.7256 / 2073-8560.2013 .02 .3$

Система и взаимодействия

Таблича 3

Распределение совокупного ВВП и мировых банковских активов, 2011 2.

\begin{tabular}{|c|c|c|c|c|c|}
\hline \multirow{2}{*}{ Регионы мира } & \multicolumn{2}{|c|}{ Совокупный ВВП } & \multicolumn{2}{|c|}{$\begin{array}{c}\text { Совокупные } \\
\text { банковские активы }\end{array}$} & \multirow{2}{*}{$\begin{array}{l}\text { Банковские } \\
\text { активы по } \\
\text { отношению к } \\
\text { ВВП, \% } \\
\quad \text { (БА/ВВП) }\end{array}$} \\
\hline & млрд.долл. & $\%$ & млрд.долл. & $\%$ & \\
\hline 1 & 2 & 3 & 4 & 5 & 6 \\
\hline Всего в мире, в том числе: & 69899.2 & 100.0 & 110378.2 & 100.0 & 157.9 \\
\hline Европейский союз*, в том числе: & 16426.5 & 23.5 & 42172.7 & 38.2 & 256.7 \\
\hline Зона Евро & 13118.5 & 18.8 & 29311.8 & 26.6 & 223.4 \\
\hline Северная Америка, в том числе: & 16814.6 & 24.1 & 18246.6 & 16.5 & 108.5 \\
\hline Канада & 1739.0 & 2.5 & 3511.3 & 3.2 & 201.9 \\
\hline США & 15075.7 & 21.6 & 14635.3 & 13.3 & 97.1 \\
\hline Япония & 5866.5 & 8.4 & 15369.3 & 13.9 & 262.0 \\
\hline $\begin{array}{l}\text { Новые индустриальные азиатские } \\
\text { экономики** }\end{array}$ & 2086.2 & 3.0 & 4381.2 & 4.0 & 210.0 \\
\hline $\begin{array}{l}\text { Развивающиеся страны и страны с } \\
\text { трансформирующейся экономикой, } \\
\text { в том числе: }\end{array}$ & 25438.4 & 36.4 & 25542.5 & 23.1 & 100.4 \\
\hline Азия & 11489.4 & 16.4 & 17940.3 & 16.3 & 156.1 \\
\hline $\begin{array}{l}\text { Латинская Америка и Карибского } \\
\text { бассейна }\end{array}$ & 5614.3 & 8.0 & 3299.5 & 3.0 & 58.8 \\
\hline Ближний Восток и Северная Африка & 2754.4 & 3.9 & 1564.6 & 1.4 & 56.8 \\
\hline Африка района Сахары & 1230.6 & 1.8 & 563.4 & 0.5 & 45.8 \\
\hline Европа & 4349.9 & 6.2 & 2174.7 & 2.0 & 50.0 \\
\hline
\end{tabular}

* - включает страны еврозоны, Данию, Швецию и Великобританию

** - включает Гонконг, Корея, Сингапур и Тайваньская область Китая

Рассчитано автором по: [17, C.11].

Проанализировав данные таблицы 3 можно сделать вывод, что большая часть мирового ВВП распределена в странах с трансформирующейся и развивающейся экономикой (36,4\% мирового ВВП). На страны Европейского союза приходится 23,5\% мирового ВВП, а на США - 21,6\%, Японию - 8,4\%.

Однако география распределения банковских активов в 2011 г. другая. Больше всего банковских активов сосредоточено в странах Европейского союза - 38,2\%, на страны с трансформирующейся экономикой и развивающиеся страны приходится
$23,1 \%$ совокупных мировых банковских активов, на Японию - 13,9\%, на США - 13,3\%.

В 2011 году в большей степени совокупные банковские активы превосходили ВВП в Японии и составили $262 \%$ ВВП страны. В совокупности по странам Европейского союза данный показатель составлял $256,7 \%$, в США банковские активы составляли 97,1\% американского ВВП.

Такое значительное превышение банковских активов над ВВП в Европе отражает значительную зависимость европейской экономики от банковского 


\section{Национальная безопасность 2(25) • 2013}

сектора и кредитов, предоставляющихся частному сектору и являющихся основным источником его финансирования.

При этом в 2010 году на 10 самых крупных банков Европы приходилось 15\% совокупных мировых банковских активов (БА/ВВП - 122\%), на 10 крупнейших банков США - 4,8\% (БА/ВВП - 44\%), на 10 крупнейших банков Японии - 3,7\% (БА/ВВП - 91\%) [18, С.12].

По состоянию на март 2012 г. распределение совокупных банковских активов по странам Европы представлено в таблице 4.

Таблища 4

Страновое распределение количества национальных и иностранных денежно-кредитных учреждений стран Евросоюза, а также величины их банковских активов, март 2012

\begin{tabular}{|c|c|c|c|c|c|c|c|c|c|}
\hline \multirow[b]{2}{*}{ № } & \multirow[b]{2}{*}{ Страна } & \multicolumn{3}{|c|}{$\begin{array}{c}\text { Денежно-кредитные } \\
\text { учреждения }\end{array}$} & \multicolumn{3}{|c|}{ Совокупные активы } & \multirow{2}{*}{$\begin{array}{c}\text { ВВП в } \\
\text { 2011, млн. } \\
\text { евро }\end{array}$} & \multirow{2}{*}{$\begin{array}{c}\text { Совокуп- } \\
\text { ные акти- } \\
\text { вы в \% } \\
\text { к ВВП }\end{array}$} \\
\hline & & $\begin{array}{c}\text { количе- } \\
\text { ство }\end{array}$ & \begin{tabular}{|c|} 
нацио- \\
нальные, \\
$\%$
\end{tabular} & $\begin{array}{c}\text { ино- } \\
\text { стран- } \\
\text { ные, \% }\end{array}$ & \begin{tabular}{|c} 
величи- \\
на, \\
млн. \\
евро
\end{tabular} & $\begin{array}{c}\text { нацио- } \\
\text { нальные, } \\
\%\end{array}$ & $\begin{array}{c}\text { ино- } \\
\text { стран- } \\
\text { ные, \% }\end{array}$ & & \\
\hline 1 & Великобритания & 373 & 51,4 & 48,6 & 9933059 & 69,0 & 31,0 & 1746962 & 568,59 \\
\hline 2 & Германия & 1893 & 95,3 & 4,7 & 8522747 & 94,8 & 5,2 & 2570800 & 331,52 \\
\hline 3 & Франция & 656 & 44,3 & 55,7 & 8454275 & 96,7 & 3,3 & 1996583 & 423,44 \\
\hline 4 & Италия & 740 & 86,6 & 13,4 & 4158073 & 91,5 & 8,5 & 1580220 & 263,13 \\
\hline 5 & Испания & 334 & 44,3 & 55,7 & 3732258 & 92,1 & 7,9 & 1073383 & 347,71 \\
\hline 6 & Нидерланды & 284 & 31,5 & 68,5 & 2480282 & 88,8 & 11,2 & 602105 & 411,94 \\
\hline 7 & Ирландия & 479 & 12,9 & 87,1 & 250 & $32,0 \$$ & 68,0 & 156 & 43899,16 \\
\hline 8 & Бельгия & 108 & 58,8 & 41,2 & 16 & 48,59 & 51,5 & 368 & $30 \$ 15,42$ \\
\hline 9 & Швеция & 174 & 87,0 & 13,0 & 1160037 & 99,6 & 0,4 & 386772 & 299,93 \\
\hline 10 & Дания & 161 & 95,3 & 4,7 & 1115073 & 87,7 & 12,3 & 239245 & 466,08 \\
\hline 11 & Люксембург & 142 & 7,1 & 92,9 & 1040680 & 7,9 & 92,1 & 42822 & 2430,25 \\
\hline 12 & Австрия & 765 & 90,9 & 9,1 & 1011062 & 74,9 & 25,1 & 300241 & 336,75 \\
\hline 13 & Финляндия & 323 & 22,2 & 77,8 & 641 & 57922,1 & 77,9 & 191 & $57 \mathrm{~B} 34,90$ \\
\hline 14 & Португалия & 155 & 50,5 & 49,5 & 580 & 73777,8 & 22,2 & 170 & 92839,76 \\
\hline 15 & Греция & 54 & 27,5 & 72,5 & 435 & 2180,8 & 19,2 & 215 & 08802,34 \\
\hline 16 & Польша & 699 & 91,9 & 8,1 & 334 & 76436,2 & 63,8 & 370 & 01490,47 \\
\hline 17 & $\begin{array}{l}\text { Чешская } \\
\text { Республика }\end{array}$ & 57 & 13,2 & 86,8 & 192 & $959 \quad 5,1$ & 94,9 & 154 & $91 \mathfrak{3} 24,56$ \\
\hline 18 & Кипр & 141 & 15,4 & 84,6 & 130 & 39068,4 & 31,4 & 17 & 76134,14 \\
\hline 19 & Венгрия & 189 & 82,6 & 17,4 & 115 & 32539,1 & 60,9 & 100 & 51314,74 \\
\hline 20 & Румыния & 41 & 17,9 & 82,1 & 90 & 66216,7 & 83,3 & 136 & 48066,43 \\
\hline 21 & Словакия & 30 & 13,3 & 86,7 & 59 & 71911,0 & 89,0 & 69 & 05886,48 \\
\hline 22 & Словения & 25 & 47,6 & 52,4 & 53 & 71453,0 & 72,6 & 35 & 63950,72 \\
\hline 23 & Малта & 26 & 38,5 & 61,5 & 51 & 16620,2 & 79,8 & 6 & 42696,23 \\
\hline 24 & Болгария & 31 & 25,8 & 74,2 & 42 & 85723,5 & 76,5 & 38 & 483111,37 \\
\hline 25 & Латвия & 30 & 21,1 & 78,9 & 28 & $348 \quad 9,9$ & 90,1 & 20 & 05041,39 \\
\hline 26 & Литва & 91 & 42,9 & 57,1 & 24 & 19837,7 & 62,3 & 30 & 70578,81 \\
\hline
\end{tabular}


DOI: $10.7256 / 2073-8560.2013 .02 .3$

Система и взаимодействия

\begin{tabular}{|l|r|r|r|r|r|r|r|r|}
\hline 27 Эстония & 17 & 95,6 & 4,4 & 19067 & 5,7 & 94,3 & 15973 & 119,37 \\
\hline Итого: & $\mathbf{8}$ & $\mathbf{0 1 8} \mathbf{7 8 , 3}$ & $\mathbf{2 1 , 7}$ & $\begin{array}{r}\mathbf{4 6 ~ 8 2 0} \\
\mathbf{1 4 6}\end{array}$ & $\mathbf{8 0 , 1}$ & $\mathbf{1 9 , 9}$ & $\mathbf{1 2 ~ 6 3 7 ~ 4 7 7}$ & $\mathbf{3 7 0 , 4 9}$ \\
\hline
\end{tabular}

Рассчитано автором по: [18].

В результате анализа данных таблицы 4 можно сделать вывод, что самые большие банковские сектора в абсолютном выражении находятся в Великобритании (9,93 трлн. евро), Германии (8,52 трлн. евро) и Франции (8,45 трлн. евро) (рис. 1). Относительно ВВП, сово- купные банковские активы в Люксинбурге (2430,25\%), в Ирландии $(799,16 \%)$, Мальте $(796,23 \%)$ и Кипре (734,14\%) являются самыми большими, в связи с тем, что данные страны являются крупнейшими оффшорными финансовыми центрами (рис.2).

Рис. 1. Страновое распределение совокупных банковских активов по 15 крупнейшим европейским экономикам, март 2012.

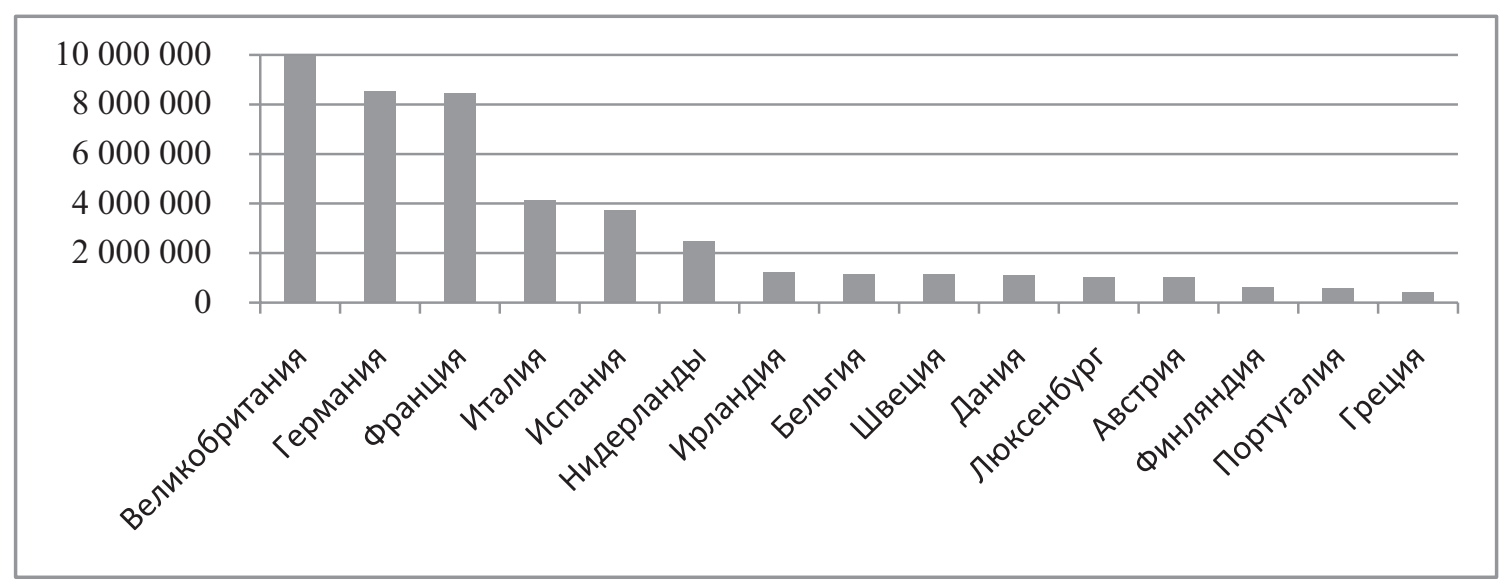

Рассчитано автором по: [18].

Рис. 2. Страновое распределение совокупных банковских активов стран Евросоюза в \% соотношении к национальному ВВП стран, март 2012.

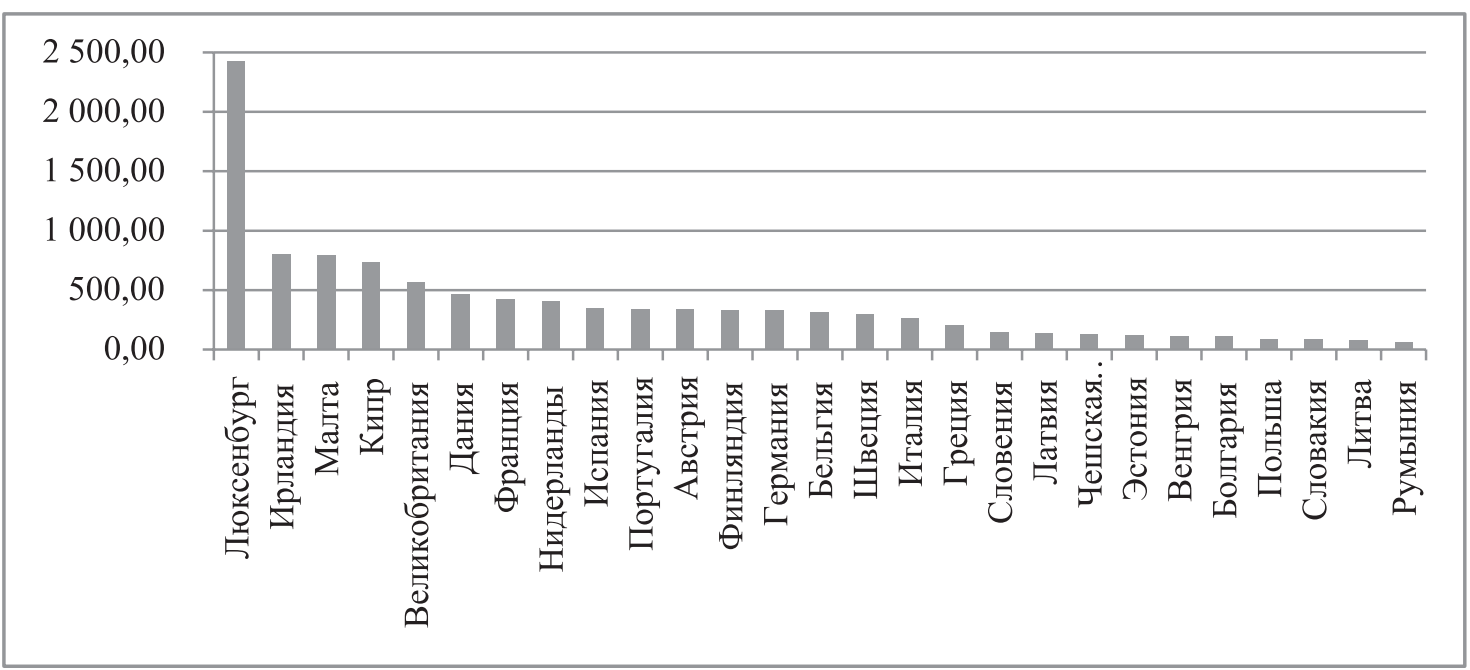

Рассчитано по: [18]. 


\section{Национальная безопасность 2(25) • 2013}

Рост банковских активов европейских стран сопровождался транснационализацией банковского бизнеса, как на территории стран ЕС, так и в мировых масштабах. Финансовая интеграция стран ЕС происходила быстрыми темпами, поощряемая необходимостью выдачи больших кредитов и другим движением капитала между странами. Европейские страны увеличивали свой международный бизнес особенно быстрыми темпами благодаря единому рынку в ЕС и еврозоне, а также единой валюте.

Транснационализация банковской деятельности стран ЕС на внутреннем европейском рынке была сильна и до кризиса. Однако степень международного проникновения банков значительно отличается между странами - членами ЕС (таблица 4). В некоторых странах-членах ЕС, особенно более крупных экономических системах: Швеция $(99,6 \%-$ национальные банковские активы), Франция (96,7\%), Германия (94,8\%), Испания $(92,1 \%)$, Нидерланды $(88,8 \%)$, Дания (87,7\%), доля иностранных банковских активов на внутреннем национальном рынке минимальна. Эти страны - члены Евросоюза являются родиной крупных банковских групп и экспортируют свои банковские услуги в другие государства - члены Евросоюза. Так доля иностранных банковских активов в совокупной величине активов банковских систем таких стран как: Чешская Республика (94,9\%), Эстония (94,3\% иностранных активов на внутреннем национальном рынке), Люксенбург (92,1\%), Латвия (90,1\%), Словакия (89\%), Румыния (83,3\%), очень велика. Банковская система указанных стран находится под огромным влиянием иностранных транснациональных банков.

Анализ странового распределения количества денежно-кредитных учреждений в европейских странах позволяет сделать вывод, что некоторые банковские рынки европейских стран находятся во власти крупных национальных банков, например, во Франции, Швеции и Великобритании. Другие банковские системы характеризуются более разнообразным банковским рынком, у которого есть и небольшие банки, например, в Австрия, Германия и Испания.

Некоторые крупнейшие европейские банки сконцентрировали банковские активы, которые намного выше, чем совокупный национальный ВВП страны основного базирования (таблица 5).

Таблииа 5

Банковские активы крупнейших европейских банков в проиентном отношении к совокупному национальному ВВП и совокупному ВВП Евросоюза, 2011 г.

\begin{tabular}{|l|l|c|c|c|c|}
\hline \multicolumn{1}{|c|}{ Банк } & \multicolumn{1}{|c|}{ Страна } & $\begin{array}{c}\text { Банковские } \\
\text { активы, } \\
\text { млн. евро }\end{array}$ & $\begin{array}{c}\text { Совокупный } \\
\text { националь- } \\
\text { ный ВВП, } \\
\text { млн. евро }\end{array}$ & $\begin{array}{c}\text { Банковские } \\
\text { активы в \% к } \\
\text { национально- } \\
\text { му ВВП }\end{array}$ & $\begin{array}{c}\text { Банковские } \\
\text { активы в \% } \\
\text { к ВВП ЕС }\end{array}$ \\
\hline Deutsche Bank & Германия & 2164103 & 2570800 & 84.18 & 17.12 \\
\hline HSBC Holdings & Великобритания & 1967796 & 1746962 & 112.64 & 15.57 \\
\hline BNP Paribas & Франция & 1965283 & 1996583 & 98.43 & 15.55 \\
\hline Credit Agricole Group & Франция & 1879536 & 1996583 & 94.14 & 14.87 \\
\hline Barclay PLC & Великобритания & 1871469 & 1746962 & 107.13 & 14.81 \\
\hline $\begin{array}{l}\text { Royal Bank of Scotland } \\
\text { Group }\end{array}$ & Великобритания & 1803649 & 1746962 & 103.24 & 14.27 \\
\hline Banco Santander & Испания & 1251525 & 1073383 & 116.60 & 9.90 \\
\hline Societe Generale & Франция & 1181372 & 1996583 & 59.17 & 9.35 \\
\hline Lloyds Banking Group & Великобритания & 1161698 & 1746962 & 66.50 & 9.19 \\
\hline Groupe BPCE & Франция & 1138395 & 1996583 & 57.02 & 9.01 \\
\hline ING Group & Нидерланды & 961165 & 602105 & 159.63 & 7.61 \\
\hline
\end{tabular}


DOI: $10.7256 / 2073-8560.2013 .02 .3$

Система и взаимодействия

\begin{tabular}{|l|l|c|c|c|c|}
\hline Uni Credit S.p.A. & Италия & 926769 & 1580220 & 58.65 & 7.33 \\
\hline Rabobank Group & Нидерланды & 731665 & 602105 & 121.52 & 5.79 \\
\hline Nordea Bank & Швеция & 716204 & 386772 & 185.17 & 5.67 \\
\hline Commerzbank & Германия & 661763 & 2570800 & 25.74 & 5.24 \\
\hline Intesa Sanpaolo & Италия & 639221 & 1580220 & 40.45 & 5.06 \\
\hline BBVA & Испания & 597688 & 1073383 & 55.68 & 4.73 \\
\hline Standard Chartered & Великобритания & 461284 & 1746962 & 26.40 & 3.65 \\
\hline Danske Bank & Дания & 460832 & 239245 & 192.62 & 3.65 \\
\hline DZ Bank AG & Германия & 405926 & 2570800 & 15.79 & 3.21 \\
\hline Landesbank Baden-W. & Германия & 373059 & 2570800 & 14.51 & 2.95 \\
\hline KBC & Бельгия & 285382 & 368304 & 77.49 & 2.26 \\
\hline Handelsbanken & Швеция & 275514 & 386772 & 71.23 & 2.18 \\
\hline SEB & Швеция & 265219 & 386772 & 68.57 & 2.10 \\
\hline Banca Montedei P.S. & Италия & 240702 & 1580220 & 15.23 & 1.90 \\
\hline Erste Bank & Австрия & 210006 & 300241 & 69.95 & 1.66 \\
\hline Swedbank & Швеция & 208464 & 386772 & 53.90 & 1.65 \\
\hline RZB AG & Австрия & 150087 & 300241 & 49.99 & 1.19 \\
\hline UBI & Италия & 129804 & 1580220 & 8.21 & 1.03 \\
\hline
\end{tabular}

Рассчитано автором по:[18].

Такими банками, например, являются: датский банк Danske Bank (192,62\% национального ВВП), шведский банк Nordea Bank (185,17\%), нидерландские банки ING Group (159,63\%) и Rabobank Group $(121,52 \%)$, что свидетельствует о существенном влиянии указанных банков на национальную экономику.

Распределение банковских активов крупнейших европейских банков в стране базирования, а также других странах ЕС и странах мира представлено в таблице 6

Таблиия 6

Распределение банковских активов крупнейших европейских банков в стране базирования, странах ЕС и других странах мира, 2009

\begin{tabular}{|c|c|c|c|c|}
\hline \multirow[b]{2}{*}{ Банк } & \multirow[b]{2}{*}{ Страна } & \multicolumn{3}{|c|}{ Распределение активов, \% } \\
\hline & & $\begin{array}{c}\text { внутри } \\
\text { страны } \\
\text { базирования }\end{array}$ & в странах EC & $\begin{array}{c}\text { в других } \\
\text { странах мира }\end{array}$ \\
\hline Deutsche Bank & Германия & 30 & 33 & 37 \\
\hline HSBC Holdings & Великобритания & 27 & 17 & 56 \\
\hline BNP Paribas & Франция & 45 & 34 & 21 \\
\hline Credit Agricole Group & Франция & 62 & 23 & 15 \\
\hline Barclay PLC & Великобритания & 39 & 16 & 45 \\
\hline
\end{tabular}


DOI: $10.7256 / 2073-8560.2013 .02 .3$

\section{Национальная безопасность 2(25) • 2013}

\begin{tabular}{|l|l|c|c|c|}
\hline Royal Bank of Scotland Group & Великобритания & 56 & 19 & 25 \\
\hline Banco Santander & Испания & 31 & 30 & 39 \\
\hline Societe Generale & Франция & 56 & 27 & 17 \\
\hline Lloyds Banking Group & Великобритания & 92 & 4 & 4 \\
\hline Groupe BPCE & Франция & 77 & 5 & 18 \\
\hline ING Group & Нидерланды & 43 & 37 & 20 \\
\hline Uni Credit S.p.A. & Италия & 41 & 24 & 35 \\
\hline Rabobank Group & Нидерланды & 65 & 14 & 21 \\
\hline Nordea Bank & Швеция & 21 & 71 & 8 \\
\hline Commerzbank & Германия & 72 & 20 & 8 \\
\hline Intesa Sanpaolo & Италия & 79 & 19 & 3 \\
\hline BBVA & Испания & 41 & 2 & 57 \\
\hline Standard Chartered & Великобритания & 15 & 0 & 85 \\
\hline Danske Bank & Дания & 52 & 44 & 3 \\
\hline Landesbank Baden-W. & Германия & 81 & 16 & 3 \\
\hline KBC & Бельгия & 47 & 36 & 17 \\
\hline
\end{tabular}

Источник: [18, C.53].

Так в странах Европы наибольшие иностранные активы имеют следующие банки: шведский банк Nordea Bank (71\%), датский банк Danske Bank (52\%), нидерландский банк ING Group (37\%), бельгийский банк КBC (36\%), французский банк BNP Paribas (34\%).

В других странах мира наибольшие иностранные активы были распределены банками Великобритании Standard Chartered (85\%), HSBC Holding (56\%), Barclay PLC (45\%) и испанским банком Banco Santander (39\%).

Процессы транснационализации банковской деятельности и увеличения банковских активов происходят и на пространстве стран СНГ.

Так совокупные активы 10 крупнейших банков СНГ (табл. 7) по состоянию на 01.01.2012 г. состави- ли 737,36 млрд. долл. и увеличились по сравнению с 01.01.2009 г. (518,80 млрд. долл.) на 42,13\%, что свидетельствует об опережающих темпах роста активов банков СНГ по сравнению с банками Европы. Однако совокупные активы 10 крупнейших банков СНГ в 3,8 раза меньше, чем активы самого крупного по активам банка Европы - Deutsche Bank и по совокупной величине не смогли войти в 20-ку крупнейших банков Европы. При этом активы испанского банка BBVA, занявшего 20 строчку среди крупнейших банков Европы (774,1 млрд. долл.) по состоянию на 01.01.2012 г. на 36,7 млрд. долл. (4,98\%) больше, чем совокупные активы 10-ти крупнейших банков СНГ.

Таблица 7

Динамика величины активов крупнейших банков СНГ за период 2009-2012 гг., млн. долл. США

\begin{tabular}{|c|c|c|c|c|c|c|}
\hline \multirow{2}{*}{$\begin{array}{c}\text { Рейтинг } \\
\text { на } \\
\text { 01.01.2012 } \\
\end{array}$} & \multirow{2}{*}{$\begin{array}{c}\text { Наименование кредитной } \\
\text { организации }\end{array}$} & \multirow{2}{*}{ Страна } & \multicolumn{4}{|c|}{ Акт и вы } \\
\hline & & & 01.01.2012 & 01.01.2011 & 01.01.2010 & 01.01.2009 \\
\hline 1 & Сбербанк России & Россия & 323623,64 & 280827,24 & 235115,85 & 228603,39 \\
\hline
\end{tabular}


DOI: $10.7256 / 2073-8560.2013 .02 .3$

Система и взаимодействия

\begin{tabular}{|r|l|l|r|r|r|r|}
\hline 2 & Банк ВТБ & Россия & 129563,88 & 91750,10 & 88401,00 & 86785,84 \\
\hline 3 & Газпромбанк & Россия & 74477,11 & 60652,36 & 56444,45 & 60353,65 \\
\hline 4 & Россельхозбанк & Россия & 42994,06 & 33394,56 & 31491,36 & 27561,09 \\
\hline 5 & Банк Москвы & Россия & 37554,33 & 27727,69 & 26020,09 & 25934,79 \\
\hline 6 & Банк ВТБ 24 & Россия & 36412,33 & 29672,53 & 23470,71 & 20469,92 \\
\hline 7 & Альфа-Банк & Россия & 28676,91 & 26391,46 & 19379,96 & 22615,68 \\
\hline 8 & ЮниКредит Банк & Россия & 27276,32 & 22010,44 & 16745,11 & 19472,00 \\
\hline 9 & Росбанк & Россия & 18618,92 & 14200,15 & 14753,55 & 16596,78 \\
\hline 10 & Приватбанк & Украина & 18162,97 & 14247,86 & 10778,48 & 10411,10 \\
\hline 11 & Райффайзенбанк & Россия & 17763,53 & 15911,00 & 15717,53 & 18887,78 \\
\hline 12 & Промсвязьбанк & Россия & 17439,50 & 15549,39 & 15268,57 & 15187,33 \\
\hline 13 & Казкоммерцбанк & Казахстан & 17291,11 & 18223,73 & 17432,30 & 21649,14 \\
\hline 14 & ТрансКредитБанк & Россия & 15631,40 & 12480,75 & 8039,64 & 8003,64 \\
\hline 15 & Народный банк Казахстана & Казахстан & 15322,98 & 14223,29 & 13626,63 & 13671,24 \\
\hline 16 & Номос-Банк & Россия & 14107,47 & 11821,45 & 8932,72 & 8960,08 \\
\hline 17 & Банк Уралсиб & Россия & 13057,97 & 13348,79 & 12274,12 & 14490,66 \\
\hline 18 & Беларусбанк & Белоруссия & 12586,96 & 17559,08 & 12547,25 & 12088,63 \\
\hline 19 & БТА Банк & Казахстан & 10893,10 & 13518,60 & 13279,28 & 24133,71 \\
\hline 20 & Мдм Банк & Россия & 10636,06 & 12373,35 & 13356,73 & 7167,66 \\
\hline
\end{tabular}

Рассчитано автором по [3, 4, 7, 11, 12].

Среди двадцати самых крупных банков СНГ лидирующее положение занимают российские банки. При этом в 20-ку крупнейших банков СНГ по состоянию на 01.01.2012 г. вошли, кроме российских банков, украинский банк Приватбанк (18,16 млрд. долл.), казахские банки: Казкоммерцбанк (17,29 млрд. долл.), Народный банк Казахстана (15,32 млрд. долл.), БТА Банк $(10,89$ млрд. долл.) и белорусский банк Беларусбанк (12,58 млрд. долл.).

Активы самого крупного банка СНГ - российского банка Сбербанк России по состоянию на 01.09.2012 г. составили 396,68 млрд. долл. [12] и возросли с начала 2012 г. на 22,58\% и на 96,91\% по сравнению с 01.01.2008 г. и по состоянию на 01.01.2012 г. составляют 43\% совокупных активов десятки крупных банков СНГ. Сбербанк России является ТНБ с дочерними банками, которые работают в Казахстане, Украине и Белоруссии. Также открыты представительства в Германии, филиал в Индии, зарегистрировано представительство в
Китае. В конце 2011 Сбербанк закрыл сделку по приобретению SLB Commercial Bank AG, переименованного в Sberbank (Switzerland) AG, а в январе 2012 банк завершил сделку по приобретению крупнейшей российской инвестиционной компании «Тройки Диалог». После приобретения Volksbank International в структуру Сбербанка вошли подразделения в 9 странах Центральной и Восточной Европы. В августе Сбербанк создал совместный банк на рынке кредитования в точках продаж с Cetelem (Группа BNP Paribas). В сентябре 2012 года Сбербанк приобрел 99,85\% акций банка Deniz Bank.

Иностранные активы банковского сектора России по состоянию на 01.01.2012 года составили 104 620,6 млн. долл., из них на страны СНГ приходилось 7 595,7 млн. долл. (7,26\%), что на 3,32\% выше, чем по состоянию на 01.01.2009 г., на страны дальнего зарубежья - 97 024,8 млн. долл. (92,74\%), в том числе настраны ЕС - 77 908,4 млн. долл. (74,47\%), а также страны АТЭС - 14 806,3 млн. долл. (рис. 3). 


\section{Национальная безопасность 2(25) 2013}

Рис. 3. Страновое распределение иностранных активов банковского сектора России, на 01.01.2012.

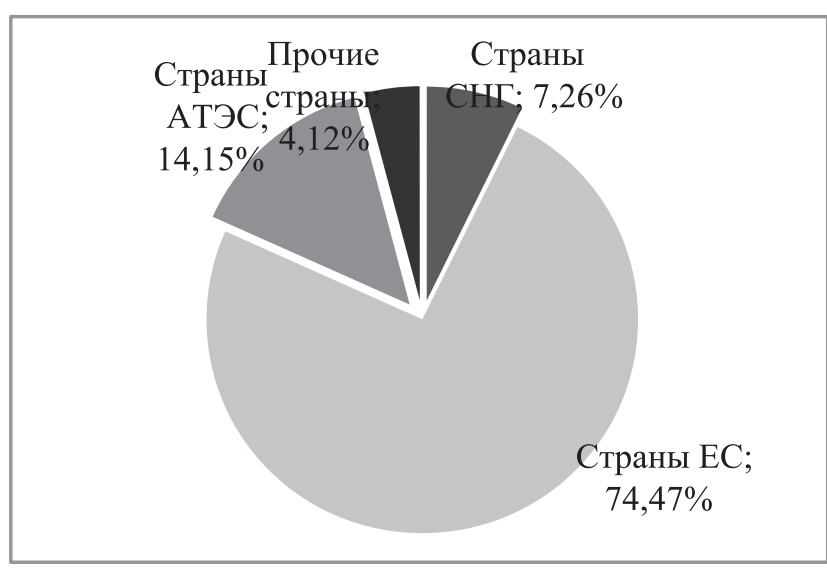

Рассчитано автором по: [9].

При анализе валютной структуры иностранных активов банкового сектора России за 2002-2012 гг. доля иностранных активов в долларах США снизилась на $20,7 \%$, в евро увеличилась на $10,3 \%$ и в рублях увеличилась на $14,2 \%$ [9].

Наибольшие иностранные банковские активы России в странах СНГ распределены в Республике Беларусь - 2 269,9 млн. долл. (2,17 \% совокупных иностранных активов). Из стран Евросоюза: в Великобритании - 27 578,1 млн. долл. (26,36 \%) и на Кипре - 10 155,7 млн. долл. (9,71\%). Из стран АТЭС - в США - 14 170,3 млн. долл. (13,54 \%).

Банковская система Республики Украина по состоянию на 01.12.2012 представлена 176 банками с совокупными активами 140,05 млрд. долл. Крупнейшим банком Украины является Приватбанк. Его активы по состоянию на 01.10.2012 г. составили 20,59 млрд. долл. [11], что составляет $14,70 \%$ от совокупных банковских активов Украины и увеличились с начала 2012 года на 2,43 млрд. долл. (13,35\%) и в 2,73 раза по сравнению с 01.01.2009 г. В рейтинге 20 крупнейших банков СНГ Приватбанк занимает 10 строчку. По состоянию на 01.01.2012 г. региональные подразделения Приватбанка представлены 35 филиалами, в том числе на Кипре. Приватбанк имеет представительства в России, Китайской Народной Республике, в Великобритании, а также дочерние банки: Москомприватбанк (Россия) (4 филиала, 67 доп. офисов, 113 операционных офисов); Банк AS «PrivatBank» (Латвия), имеющим 14 филиалов, в том числе в г. Лисабоне (Португалия), в г. Рим (Италия); дочерний банк АТ «Приватбанк» Грузия (103 сервис-центра).
По состоянию на 01.10.2012 г. банковская система Казахстана представлена 38 банками второго уровня с совокупными активами 89,72 млрд. долл. Крупнейшим банком Казахстана является АО «Казкоммерцбанк», активы которого по состоянию на 01.10.2012 г. составили 17,08 млрд. долл. [7] что составляет 19,04\% совокупных банковских активов Казахстана. С 2008 г. в Таджикистане начал свою работу его дочерний банк. В том же 2008 г. банк получает в доверительное управление $100 \%$ долей в уставном капитале Москоммерцбанка (Россия). С 2008 г. крупнейшим акционером банка становится частный арабский инвестиционный фонд AlnairCapitalHolding.

На 1 января 2013 г. банковский сектор Республики Беларусь включал 32 банка, из которых 26 банков являлись банками с участием иностранного капитала. Крупнейшим банком Республики Беларусь является Акционерный Сберегательный банк «Беларусбанк», банковские активы которого по состоянию на 01.10.2012 г. составили 14,77 млрд. долл. [4], и увеличились с начала 2012 года на 2.18 млрд. долл. (17,34\%). В 1996 г. в состав банка вошли банки Белсвязьбанк и Белжелдорбанк. В 1997 г. было открыто представительство России и Польше, в 2003 г. - в Германии, в июне 2007 г. - в Пекине. В августе 2011 г. по обзору The Banker Беларусбанк занял 441-е место среди 1000 самых крупных банков мира и вошел в число 25 крупнейших банков Центральной и Восточной Европы по размеру капитала первого уровня.

По величине активов в сотню банков СНГ по состоянию на 01.01.2012 г. не вошли банки Армении, Киргизии, Молдовы, Таджикистана и Туркмении.

Усиление значимости транснациональных банков в мировой экономике отражает дальнейшее развитие глобализационных процессов в мировой валютной системе. Формируется тенденция валютно-финансового разделения мира между могущественными банковскими группами, каждый из которых обладает колоссальными мощью и влиянием на сферы мировой экономики и регионально-отраслевые сегменты, включая мировую валютную систему.

Глобальный валютно-финансовый кризис внес существенные изменения в сложившуюся до недавнего времени мировую валютную систему и показал, что проблемы отдельных крупнейших банков могут стать проблемами целых стран и мировой валютнофинансовой системы в целом.

Реформы, проводимые в пятилетний период после начала глобального валютно-финансового 
кризиса, как утверждает МВФ, хотя и имеют позитивную направленность, еще не привели к созданию более безопасной системы финансовых структур, а некоторые наиболее трудные проблемы остаются нерешенными. Так, МВФ в аналитической главе «Доклада по вопросам глобальной финансовой стабильности» от октября 2012 г. указывает, что хотя намерения директивных органов являются очевидными и положительными, эти реформы еще не привели к созданию более безопасной системы финансовых структур, отчасти из-за того, что в некоторых странах и регионах меры вмешательства, необходимые для преодоления затяжного кризиса, задерживают переориентацию системы на более безопасный путь [22].

Для повышения макроэкономической стабильности, обеспечения долгосрочной устойчивости мировой валютно-финансовой системы необходимо осуществить целый ряд взаимосвязанных изменений на всех уровнях, в том числе, укрепление финансовой системы и развитие финансовой интеграции в целях содействия экономическому росту [5, С.44], реформирования системы банковского надзора и регулирования на национальном и международном уровнях.

С целью реформирования системы регулирования финансового сектора на международном уровне, повышения надежности финансовых рынков и создания эффективной регуляторной и надзорной политики в мировой валютно-финансовой системе на саммите «G-20» в апреле 2009 г. было принято решение о преобразовании Форума по финансовой стабильности (образован в 1999 г. на встрече «G-7» в Бонне) в Совет по финансовой стабильности (анг. Financial Stability Board - FSB) [6], основными задачами которого, в том числе, являются: анализ факторов уязвимости, затрагивающих финансовую систему, определение и контроль исполнения соответствующих мер; установление руководящих принципов в отношении создания надзорных коллегиальных органов и участия в них, в том числе, посредством постоянной работы по определению наиболее важных системно значимых транснациональных компаний; планирование принятия чрезвычайных мер по урегулированию трансграничных кризисов, в частности в отношении системно значимых финансовых учреждений; участие, совместно с МВФ, в мероприятиях по раннему выявлению и предупреждению возникающих макроэкономических и финансовых рисков и др.

От России в состав FSB вошли представители Банка России, Федеральной службы по финансовым рынкам и Министерства Финансов РФ.

Международный валютный фонд совместно с FSB и Банком международных расчетов в 2009 году провел исследования с целью выявления системно значимых финансовых учреждений, под которыми следует понимать такие финансовые учреждения, чей размер и характер деятельности таковы, что их банкротство или невозможность продолжения деятельности будут с большей вероятностью иметь негативные последствия для эффективного функционирования финансовых рынков или для других финансовых учреждений в системе [1, С.14].

Для определения системной значимости финансовых учреждений существуют различные подходы. При этом, при индикаторном подходе применяются ряд показателей, среди которых используется показатель совокупных банковских активов в процентах от национального ВВП [23], подробно рассмотренный в настоящей статье.

В ноябре 2011 г. [24] FSB опубликовал первоначальный список системно значимых финансовых учреждений (SIFIs), состоящий из 29 транснациональных банков (табл.8), к которым будут применяться более интенсивные и эффективные надзорные меры. Данный список обновляется ежегодно.

Таблицьа 8

Перечень системно значимых мировых финансовых учреждений, по состоянию на 1 октября 2012 г., млрд. долл. США

\begin{tabular}{|c|l|l|c|c|c|c|c|}
\hline $\begin{array}{c}\text { Рей- } \\
\text { тинг }\end{array}$ & \multicolumn{1}{|c|}{ Банк } & \multicolumn{1}{|c|}{ Страна } & Активы & $\begin{array}{c}\text { Рей- } \\
\text { тинг }\end{array}$ & \multicolumn{1}{|c|}{ Банк } & \multicolumn{1}{|c|}{ Страна } & Активы \\
\hline 1 & Deutsche Bank & Германия & 2809,89 & 16 & ING Group & Нидерланды & 1604,57 \\
\hline 2 & $\begin{array}{l}\text { Mistsubishi UFJ } \\
\text { Financial Group }\end{array}$ & Япония & 2803,42 & 17 & Groupe BРCE & Франция & 1531,08 \\
\hline
\end{tabular}


DOI: $10.7256 / 2073-8560.2013 .02 .3$

Национальная безопасность 2(25) • 2013

\begin{tabular}{|c|l|l|l|l|l|l|l|}
\hline 3 & HSBC Holding & Великобритания & 2721,06 & 18 & $\begin{array}{l}\text { Lloyds Banking } \\
\text { Group }\end{array}$ & Великобритания & 1529,12 \\
\hline 4 & Barclays PLC & Великобритания & 2584,30 & 19 & UBS & Швейцария & 1456,45 \\
\hline 5 & BNP Paribas & Франция & 2562,99 & 20 & WellsFargo & США & 1374,72 \\
\hline 6 & $\begin{array}{l}\text { JPMorgan } \\
\text { Chase\&Co. }\end{array}$ & США & 2321,28 & 21 & UniCreditS.p.А. & Италия & 1245,95 \\
\hline 7 & Credit Agricole SA & Франция & 2317,12 & 22 & $\begin{array}{l}\text { Credit Suisse } \\
\text { Group AG }\end{array}$ & Швейцария & 1088,60 \\
\hline 8 & $\begin{array}{l}\text { Royal Bank of } \\
\text { Scotland Group }\end{array}$ & Великобритания & 2225,14 & 23 & Goldman Sachs & США & 949,47 \\
\hline 9 & Bank of America & США & 2168,02 & 24 & Nordea Bank & Шведция & 914,06 \\
\hline 10 & $\begin{array}{l}\text { Mizuho Financial } \\
\text { Group }\end{array}$ & Япония & 2123,32 & 25 & Commerzbank & Германия & 868,51 \\
\hline 11 & Bank of China & Китай & 2027,41 & 26 & Morgan Stanley & США & 764,98 \\
\hline 12 & Citigroup Inc & США & 1931,35 & 27 & Dexia SA & Бельгия & 528,59 \\
\hline 13 & $\begin{array}{l}\text { Sumitomo Mitsui } \\
\text { FinancialGroup }\end{array}$ & Япония & 1788,23 & 28 & $\begin{array}{l}\text { Bank of New } \\
\text { York Mellon }\end{array}$ & США & 357,29 \\
\hline 14 & Banco Santander & Испания & 1672,11 & 29 & $\begin{array}{l}\text { State Street } \\
\text { Corp }\end{array}$ & США & 216,83 \\
\hline 15 & Societe Generale & Франция & 1647,51 & & & & \\
\hline
\end{tabular}

Составлено автором по [1, 14].

С целью повышения экономической безопасности и стабильности валютно-финансовой системы Европейского союза (ЕС) на саммите 27 стран ЕС в октябре 2012 г. в Брюсселе было принято решение о создании европейского Банковского союза с единым банковским надзорным механизмом (анг. Single Supervisory Mechanism - SSM), нормативные рамки которого должны быть определены к марту 2013 г., a c 1 марта 2014 г. начать работу в полном объеме.

При этом централизованному банковскому надзору со стороны нового органа будут подвержены только те банки, баланс которых превышает 30 миллиардов евро или составляет более 20\% ВВП основной страны базирования, но в любом случае под контроль Европейского центрального банка подпадут три самых крупных финансовых учреждения каждой страны - члена ЕС.

В России в соответствии со «Стратегией-2020: Новая модель роста - новая социальная политика» $[13$, C.201] планируется на базе Банка России создание Совета по финансовой стабильности. В состав совета с правом голоса предполагается включить руково- дителей Банка России, Министерства финансов и ФСФР, без права голоса - глав Минэкономразвития, Федеральной антимонопольной службы и Агентства по страхованию вкладов. В состав рекомендательного органа предполагается включить действующих представителей от России в FSB.

В полномочия Совета по финансовой стабильности будет входить мониторинг ситуации на различных финансовых рынках и реализация мер, в том числе, временных и мер микропруденциального регулирования, для предотвращения «перегрева» и «пузырей», а также мониторинга за накоплением рисков на балансах всех крупных системно значимых финансовых учреждений. В настоящее время эти функции возложены на Департамент финансовой стабильности Банка России, но этот уровень недостаточен для принятия взвешенных решений по всем возможным проблемам макропруденциального характера, в том числе, из-за отсутствия механизма координации деятельности основных регуляторов финансового рынка. 


\section{Библиография:}

1. Айвазян С.А., Андриевская И.К., Конноли Р., Пеникас Г.И. Выявление системнозначимых финансовых организаций: обзор методологий // Деньги и кредит. 2011. №8. С.13-18.

2. Арсенова Л.А. Воздействия транснациональных банков на националь-ную экономику и финансовые рынки стран присутствия. //Валютное регулиро-вание и валютный контроль. 2011. №5. C.4-11.

3. Банк России. Раскрытие информации кредитными организациями. Го-довая отчетность// www. cbr.ru/credit/transparent.asp

4. Беларусбанк. Бухгалтерский баланс на 01.10.2012 г. // www.belarusbank.by/ru/deyatelnost/11163/11164

5. Глазьев С.Ю., Байзаков С.Б., Ершов М.В., Митяев Д.А., Фетисов Г.Г. О реформировании глобальной валютно-финансовой системы и стимулировании экономического роста. Предложения для G20 // Деньги и кредит. 2012. № 7. С.43-47.

6. Заявление об укреплении финансовой системы. Саммит глав государств и правительств «Группы двадцати». 2 апреля 2009 //http: www. президент.pф/ref_notes/178.

7. Казкоммерцбанк. Промежуточный консолидированный отчет о финансовом положении // www.kkb.kz/attach/Financial Reports

8. Либман А.М., Хейфец Б.А. Мировые процессы транснационализации и российский бизнес. // Вопросы экономики. 2006. №12. С.61-79

9. Платежный баланс и внешний долг Российской Федерации за 2011 г. // Вестник Банка России. 2012. №24-25(№1342-1343).

10. Платонова И.Н., Наговицин А. Г., Коротченя В.М. Перестройка миро-вой валютной системы и позиции России.-М.: Книжный дом «Либроком», 2009.-240 с.

11. Приватбанк. Ежеквартальная финансовая отчетность //old.privatbank.ua/html/2_11r.html

12. Сбербанк России. Промежуточная консолидированная отчетность по МСФО // www.sbrf.ru/moscow/ru/ investor_relations/ccountability/fin_reports_ifrs/.

13. Стратегия-2020: Новая модель роста - новая социальная политика. Итоговый доклад о результатах экспертной работы по актуальным проблемам социально-экономической стратегии России на период до 2020 г.// http:www.2020strategy.ru/ data/2012/03/14/1214585998/1itog.pdf

14. Banks around the World// www.relbanks.com

15. Barclays PLC// www.barclays.com
16. Deutsche Bank AG // www.db.com

17. Global Financial Stability Report. Statistical appendix. October $2012 / /$ http://www.imf.org/External/ Pubs/FT/GFSR/2012/02/pdf/statapp.pdf

18. High-Level Expert Group on reforming the structure of the EU banking sector. Chaired by Erkki Liikanen. Final Report. Brussels, 2 October 2012 // http://ec.europa.eu/internal_market/bank/docs/ high-level_expert_group/report_en.pdf

19. HSBC Holding plc // www.hsbc.com

20. Industrial and Commercial Bank of China // www.ccb.com

21. Mistsubishi UFJ Financial Group // www.mizuho-fg. co.jp/English

22. Global Financial Stability Report. Restoring Confidence and Progressing on Reforms. International Monetary Fund, October 2012 // http://www.imf.org/ external/pubs/ft/gfsr/2012/02/pdf/text.pdf

23. Guidance to Assess the Systemic Importance of Financial Institutions, Markets and Instruments: Initial Considerations. Report to the G-20 Finance Ministers and Central Bank Governors// http:www. imf.org/external/np/g20/pdf/100109.pdf.

24. FSB announces policy measures to address systemically important financial institutions (SIFIs) and names initial group of global SIFIs // http:www. financialstabilityboard.org/press/pr_111104cc.pdf

\section{References (transliteration):}

1. Ayvazyan S.A., Andrievskaya I.K., Konnoli R., Penikas G.I. Vyyavlenie sistemnoznachimykh finansovykh organizatsiy: obzor metodologiy // Den'gi i kredit. 2011. №8. S.13-18.

2. Arsenova L.A. Vozdeystviya transnatsional'nykh bankov na natsional'-nuyu ekonomiku i finansovye rynki stran prisutstviya. //Valyutnoe reguliro-vanie i valyutnyy kontrol'. 2011. №5. S.4-11.

3. Glaz'ev S.Yu., Bayzakov S.B., Ershov M.V., Mityaev D.A., Fetisov G.G. O reformirovanii global'noy valyutno-finansovoy sistemy i stimulirova-nii ekonomicheskogo rosta. Predlozheniya dlya G20 // Den'gi i kredit. 2012. № 7. S.43-47.

4. Libman A.M., Kheyfets B.A. Mirovye protsessy transnatsionalizatsii i rossiyskiy biznes. // Voprosy ekonomiki. 2006. №12. S.61-79

5. Platonova I.N., Nagovitsin A. G., Korotchenya V.M. Perestroyka miro-voy valyutnoy sistemy i pozitsii Rossii. - M.: Knizhnyy dom «Librokom», 2009. - 240 s. 